\title{
Building Envelope Design for climate change mitigation: a case-study of hotels in Greece
}

\author{
I. Farrou ${ }^{\mathrm{a} *}$, M. Kolokotroni ${ }^{\mathrm{a}}$, M. Santamouris ${ }^{\mathrm{b}}$ \\ ${ }^{a}$ School of Engineering and Design, Brunel University, Uxbridge, Middlesex, UK \\ ${ }^{a}$ School of Engineering and Design, Brunel University, Uxbridge, Middlesex, UK \\ ${ }^{b}$ Physics Department, Group Building Environmental Research,National and \\ Kapodestrian University of Athens, Athens, Greece \\ *Corresponding author Email: ifarrou@cres.gr
}

\section{Building Envelope Design for climate change mitigation: a case-study of hotels in Greece}

This paper presents results of a study of the impact of future climate change scenarios as developed by the Intergovernmental Panel on Climate Change (IPCC) and implemented in weather files for specific future time slices (2020, 2050 and 2080) for the three climatic regions of Greece on the design of the external envelope of a hotel building in Greece. The impact of climate change on the hotel is assessed via hourly simulations of a calibrated model developed using the software TRNSYS. Additionally, the paper aims to identify optimal refurbishment strategies given the constraints of the existing case-study building when transposed to the three different climatic zones in Greece. Two modes of the hotel building were studied: 'all year' and 'seasonally' operated. It was found that different external envelope energy efficient strategies can be applied depending on the climatic zone and whether the hotel is all year or seasonally operated.

Keywords: Climate change, generation of future files, morphing method, mitigation strategies, degree days 


\section{Introduction}

Future climate change is defined by an increase in the Greenhouse Gas emissions (GHG) and in turn in the global mean temperatures (IPCC, 2011; European Environment Agency, 2004). The evaluation of the climate change is uncertain since the climate process is not totally predictable and the socio-economic development is a complex procedure. However, using projections of greenhouse gas emissions in the future, several scenarios have been modelled combining possible future $\mathrm{CO}_{2}$ concentration and social-economic development in order to predict possible increase of mean temperature. The main aim of these scenarios is to achieve stabilization of the GHG concentration in the future.

The main objective of this paper is to assess the impact of the climate change on the energy demand of a hotel building using real climatic data and future climate change scenarios as developed by the Intergovernmental Panel on Climate Change (IPCC) and implemented in weather files for specific future time slices (2020, 2050 and 2080) on the design of the external envelope of a hotel building in Greece.

\section{Literature}

The increase of the Greenhouse gases in the atmosphere is significant. Compared to the pre-industrial period (1750), the carbon dioxide $\left(\mathrm{CO}_{2}\right)$ concentration has been increased by $34 \%$, methane $\left(\mathrm{CH}_{4}\right)$ by $153 \%$ and nitrous oxide $\left(\mathrm{N}_{2} \mathrm{O}\right)$ by $17 \%$. If expressing each greenhouse gas as a $\mathrm{CO}_{2}$-equivalent, then the total concentration of GHG has increased by $170 \mathrm{ppm} \mathrm{CO}_{2}$-equivalents since the pre-industrial period. Concentrations of $\mathrm{CO}_{2}$ and $\mathrm{N}_{2} \mathrm{O}$ increase at rates similar to those of the past decades whereas concentrations of fluorinated greenhouse gases (PFCs, HFCs, \&SF6) increase rapidly mainly because they are substitutes for ozone depleting gases, (European Environment Agency, 2004). As already mentioned, because of the increase of the GHG there is an increase of the global mean temperature by $0.7^{\circ} \mathrm{C}$ over the past 100 years. The warmest year was 1998 followed by 2002 and 2003 (European Environment Agency, 2004; Frank, 2005). The increase of the European mean temperature was higher with a $0.95^{\circ} \mathrm{C}$ increase since 1900. The projected temperature increase between 1990 and 2100 is likely to range between $1.4-5.8^{\circ} \mathrm{C}$ for the global mean and $2-6.3^{\circ} \mathrm{C}$ for Europe.

The energy use in buildings is correlated to the external temperature. Several studies are carried out in order to assess the energy penalty of buildings because of the 
increased urban temperatures caused by the urban heat island and climate change, (Kolokotroni, 2007; Santamouris et.al.,2001; Hassid et al., 2000;Kapsomenakis 2013). As this relation is non-linear, the method of the degree days is proposed to be used to calculate the energy consumption of buildings according to the variations of the external temperature (Giannakopoulos et al., 2009; Committee for the Study of the Climate Change Impact, 2011; CIBSE TM41, 2006; Cartalis et al., 2001; Tselepidaki et al., 1994). Such a method implies that solar and internal gains do not represent a very significant part of the energy load. The degree days show the summation of temperature differences between a reference temperature and the outdoor air temperature. The reference temperature is known as the base temperature,which for buildings, is a balance point temperature, i.e. the outdoor temperature at which the heating or cooling systems do not need to run in order to maintain comfort conditions (CIBSE TM 41, 2006). The most appropriate base temperature for any particular building depends on the temperature that the building is heated or cooled to, and the nature of the building. The base temperature for heating and cooling may be different or the same and varies in the literature. For example, in the case of Greece, the proposed reference base values are $15.5^{\circ} \mathrm{C}$ and $18.0^{\circ} \mathrm{C}$ for $\mathrm{HDD}$ and $26.0^{\circ} \mathrm{C}$ for $\mathrm{CDD}$ respectively (Cartalis et al., 2001), for the specific calculation of the CDDs for the four summer months (June to September) base temperatures of $25^{\circ} \mathrm{C}$ and $28^{\circ} \mathrm{C}$ are used (Tselepidaki et al., 1994), temperature of $15^{\circ} \mathrm{C}$ are used for the calculation of HDDs and $25^{\circ} \mathrm{C}$ for the calculation of CDDs, (Giannakopoulos et al., 2009). According to the national guidelines (Technical Chamber of Greece, 20701-1/2010), the base temperature for HDD is $18^{\circ} \mathrm{C}$ and for CDD is $26^{\circ} \mathrm{C}$. The differences in the cumulative numbers of CDDs and HDDs between the reference and the future period show the changes in the energy demand of buildings.

In general, due to the climate change and the increase of the air temperature, more cooling will be required in the Mediterranean countries. The increase in cooling requirements will be larger over Southern Spain, the Eastern parts of Greece, Western Turkey and more so over Cyprus/North Africa. The largest requirements of cooling will be required during the dry period in the summer. It is calculated that in the North Africa more than one additional month of heavy cooling will be required whereas over parts of Southern Spain and Italy, Eastern Greece, Western Turkey and Cyprus 15 more days of heavy cooling will be needed. Until now, the increase of the cooling requirements in Greece is correlated to the increased use of air-conditioning and the associated problems 
of supply of electric power during the peak periods (i.e. blackout) and the sick -building syndrome.On the other hand, the heating requirements will be decreased during all seasons, especially spring and winter. Continental areas of Europe like Northern Spain, central Italy, Greece and Turkey will require less heating. It is calculated that the days that will require heating more than $5^{\circ} \mathrm{C}$ will be less by 20 in these countries and by one week in the islands of the Mediterranean sea for the period 2021-2050 (Giannakopoulos et al., 2009; Committee for the Study of the Climate Change Impact, 2011). The decrease of the heating requirements is involved with the less use and dependency on fuel (i.e. oil).

Due to the climate change in Greece, it is predicted an increase on the number of days that average external temperature will be higher than $35^{\circ} \mathrm{C}$, thus increasing the thermal dissatisfaction of the population. In the mainland of Greece, Thraki and Central Macedonia 20 more 'warm' days will be experienced in the period 2021-2050 (compared to the reference year 1961-1990) and 40 more 'warm' days in the period 2071-2100. In Crete and Attiki the number of additional 'warm' days is calculated to around 15.Additionally the number of 'warm' nights when the minimal temperature is above $20^{\circ} \mathrm{C}$ will be increased.. Crete and the coastal areas will be affected more where the additional 'warm' nights are predicted to 40 for the period 2021-2050 and to 80 for the period 2071-2100.In Crete and Attiki the number of additional 'warm' days is calculated to around 15. Additionally the number of 'warm' nights when the minimal temperature is above $20{ }^{\circ} \mathrm{C}$ will be increased. This also influences the thermal dissatisfaction of the population, during the periods of heatwaves (Giannakopoulos et al., 2009).

Many studies focus on simulations using projected future files in order to predict the impact of the climate change on the building energy use (Oxizidis et al., 2008; Eames et al., 2012, Guan, 2009; Guan, 2012; Jentsch et al., 2008). Additionally, in the literature four methods appear for the preparation of future weather data, these include: the extrapolating statistic method, the morphing procedure based on the imposed offset method, the stochastic weather model and global climate models. According to the literature, the comparison and analysis of these four methods conclude that the morphing method is the most reliable one for building simulations (Belcher et al. 2005; Chan, 2011; Chan, 2011b; Robert et Kummert, 2012; Guan, 2009). The main advantage of the method is that the future climates are produced by reliable present day climates 
and the main disadvantage is that the future climates rely on the variability and character of the present - day files (Belcher et al 2005; Guan 2009).

The literature reveals (Wan et al., 2011; Wan et al., 2012; Xu et al., 2012; Ouedraogo et al., 2012; Giannakidis et al., 2011; Kolokotroni et al., 2012) that due to the climate change the cooling load of buildings is expected to rise and the heating load to decline in areas with hot summer periods. Taking into consideration that currently cooling is provided mainly by electricity, there will be a huge increase of the fuel's demand. The consequences of its increased use are already known (peak demand in summer months, power generation capacity, increased cost, sick syndrome buildings and indoor air quality) and indicate the need to develop other alternatives for cooling supply and generation especially in areas with hot summer. Additionally, as more cooling will be needed than heating, primary energy will change according to the energy demand.

In order to respond to the significant increase of the energy consumption of buildings caused by the global climate change and the urban heat island, important adaptation and mitigation techniques are proposed for urban settlements and individual buildings (Santamouris, 2012). Mitigation techniques are based among others, on the use of advanced materials for cities and buildings like the so called reflective materials, (Santamouris et al., 2011;Kolokotroni et al., 2013; Synnefa et al., 2012), the use of advanced insulation materials, (Papadopoulos, 2005;Mavromatides et al., 2012), the application of intelligent passive cooling techniques, (Santamouris et Kolokotsa, 2013), the use of advanced HVAC systems, (Avgelis et Papadopoulos, 2009), etc. The application of these specific technologies has been proven to be very beneficial for buildings and cities decreasing the ambient temperature and improving indoor climatic conditions and comfort (Santamouris et al., 2012b; Mastrapostoli et al., 2014). 


\section{Methodology}

The impact of the climate change is computed by modelling a hotel building. The case study is a real building and is located in climatic zone B of Greece. The simulations are carried out using the software TRNSYS. The impact of the climate change is assessed a. for the period 1970 - 2010 using real monitored climatic data for the area of Athens, provided by the Hellenic National Meteorological Service and b. for the years 2020, 2050 and 2080 using generated future files for Patra (climatic zone B), Thessaloniki (climatic zone C) and Iraklio of Crete (climatic zone A), (Figure 1).

Future climate weather files are constructed for the three climatic regions $\mathrm{A}, \mathrm{B}$ and $\mathrm{C}$ using METEONORM data and the 'morphing' method developed by (Belcher et al., 2005 as described in section 3.2.2) using a weather generator software (Weather Generator v1). Then climate change mitigation strategies are defined for an optimum building envelope design for climatic zone B. The effectiveness of these strategies is also assessed for the climatic zones A, C of Greece. It is found that different strategies can be applied to all year and seasonally operated buildings for the most energy efficient performance.

\subsection{Description of the case study hotel}

The case study hotel building is located in Peloponese, in the Loggos area, $7.5 \mathrm{klm}$ away from the city of Aegio, and west of Athens (Greece). Its construction dates back to 1972. The hotel hasa total heated area of $5000 \mathrm{~m}^{2}$ of which $2550 \mathrm{~m}^{2}$ is cooled. The building comprises 115 rooms, reception area, restaurant, kitchen facilities, lounge with bar and one meeting room. The hotel operates from April to October and occasionally, during the heating period, i.e. during the Christmas holidays.The hotel isa freestanding building and located next to the sea. The building has a rectangular layout with the main facades facing northwest and southeast (Figure 2).

The building elements are from brickwork and have no insulation. For the purposes of the thermal simulations the U-values of the building elements comply with the typical values for constructions before 1979 as these are defined in the national legislation TOTEE 20701-1/2010 (Table 1). The building systems of the hotel building are shown in Table 2.The floor slabs provide shading to the southeast and northwest windows (Figure 3, Figure 4). 
According to the angles between the window and the shading element, the shading factors are given in table 3.19 pp71 of the Technical Chamber of Greece 20701$1 / 2010$ and are shown in Table 3.

\subsubsection{Monitored data for the period 1970-2010}

The monitored data is for the area of Athens and refers to the period 1970-2010. The monitored data includes 2 weather variables: temperature $\left({ }^{\circ} \mathrm{C}\right)$ and relative humidity (\%) on hourly basis.Apart from the years 1987 and 1988 where extreme maximum temperatures were monitored, the temperature curve presents high fluctuations and is characterized by an increasing trend from 1970 to year 2010 (Figure 5). This increasing trend is very obvious in the case of the maximum temperatures and less in the case of the average temperatures. Characteristically, the recorded maximum temperatures take values from $34.8^{\circ} \mathrm{C}$ to $38.2^{\circ} \mathrm{C}$ for the first decade (1970-1980) whereas the maximum temperatures for the last decade (2000-2010) vary from $36.2^{\circ} \mathrm{C}$ to $41^{\circ} \mathrm{C}$. Concerning the minimum temperatures, these present high fluctuations, with higher positive values during the period 1992-2000 and the lowest negative values during the period 2000-2008, and the lowest value $-4.2^{\circ} \mathrm{C}$ recorded in year 2008 . Relative humidity is the ratio of the actual amount of water vapor in a given volume of air to the amount which could be present if the air were saturated at the same temperature. Since warm air holds more moisture than cold air, the percentage of relative humidity is expected to decrease when the air temperature increases. This decrease of the relative humidity is noted in the average values and is more evident in the case of the minimum values. In means of maximum values the relative humidity also presents a slight increase of $1-2 \%$ through the years, (Figure 6).

\subsubsection{Future Climate files for the year 2020, 2050, 2080}

The future files for the building simulations are generated using the CCWorldWeather Generator tool, developed by Southampton University (Southampton University, 2010; Jentsch, 2010; Jentsch et al., 2008). The tool uses the 'morphing method', developed by (Belcher et al., 2005). The 'morphing' methodology is published by the Chartered Institution of Building Services Engineers (CIBSE) and is utilised as a baseline for transforming current CIBSE Test Reference Years (TRY) and Design Summer Years (DSY) into climate change weather years (Jentsch et al., 2008). As 
described in the literature, 'Morphing involves shifting and stretching the climatic variables in the present -day weather time series to produce new weather time series that encapsulate the average climate change while preserving the physically realistic weather sequences of the source data' (Belcher et al., 2005; Chan, 2011).

The algorithms used in the morphing method are described by the following equations (Belcher et al., 2005; Chan, 2011):

$\mathrm{x}=\mathrm{x}_{\mathrm{o}}+\Delta \mathrm{x}_{\mathrm{m}},($ shift $)$

$\mathrm{x}=\alpha_{\mathrm{m}} \mathrm{x}_{\mathrm{o}}($ linear stretch)

$\mathrm{x}=\mathrm{x}_{\mathrm{o}}+\Delta \mathrm{x}_{\mathrm{m}}+\alpha_{\mathrm{m}} \chi\left(\mathrm{x}_{\mathrm{o}}-\left(\mathrm{x}_{\mathrm{o}}\right)_{\mathrm{m}}\right)$ (a combination of shift and stretch)

where:

$\mathrm{x}_{0}$ : the existing hourly climatic data,

$\Delta \mathrm{x}_{\mathrm{m}}$ : the absolute change in monthly-mean climatic variable for month $\mathrm{m}$,

$\alpha_{\mathrm{m}}$ : the fractional change in monthly -mean climatic variable for month $\mathrm{m}$ and

$\left(\mathrm{x}_{\mathrm{o}}\right)_{\mathrm{m}}$ : the climatic variable xo average over month $\mathrm{m}$.

The tool enables the generation of future climatic files ready for use in building simulation programs. It is Microsoft Excel based and transforms 'present-day' EPW or TMY files into future files (Jentsch et al., 2008). The toolkit uses IPCC TAR model summary data of the HadCM3 A2 experiment ensemble which is available from the IPCC Data Distribution Centre.

\section{Analysis of the climatic files with the degree hours method}

The climatic data is analysed with the mean degree hours using the formulas below as given in CIBSE TM 41. 
$D_{\mathrm{d}}=\frac{\sum_{j=1}^{24}\left(\theta_{\mathrm{b}}-\theta_{0, j}\right)_{\left(\left(\theta_{\mathrm{b}}-\theta_{0, j}\right)>0\right)}}{24}$

HDD

$D_{\mathrm{d}}=\frac{\sum_{j=1}^{24}\left(\theta_{0, j}-\theta_{\mathrm{b}}\right)_{\left(\left(\theta_{0, j}-\theta_{\mathrm{b}}\right)>0\right)}}{24}$

CDD (5)

Where:

Dd is the daily degree-days for one day,

$\theta b$ is the base temperature and

$\theta o, j$ is the outdoor temperature in hour $\mathrm{j}$.

Only the positive values are considered,(CIBSE TM41, 2006).

As default by the Technical Chamber of Greece, the base temperature for heating degree days is $18^{\circ} \mathrm{C}$ and $26^{\circ} \mathrm{C}$ for cooling degree days (Technical Chamber of Greece 20701-3, 2010).

Degree days are the summation of the temperature difference between the base temperature and the outdoor air temperature. The heating degree days are calculated by subtracting each outdoor temperature from the base temperature; the summation of these differences would give daily degree hours and dividing this by 24 gives a value in degree days (CIBSE TM41, 2006). The cooling degree days are calculated by subtracting the base temperature from each outdoor temperature and by summing the positive differences.

\subsection{Monitored data for the period 1970-2010}

Table 4 presents the mean degree cooling and heating hours for the area of Athens for the period 1970-2010.

An increasing trend characterizes the mean cooling degree days and a decreasing trend characterises the heating degree days. Between the years 1970-2010 the increase in the mean cooling degree hours is calculated to $78 \%$ whereas the decrease of the heating degree days is $18 \%$ in 2010 compared to year 1970 . 


\subsection{Generated future files 2020, 2050 and 2080}

The cooling and heating degree days for Patra (climatic zone B),Thessaloniki (climatic zone C) and Iraklio (climatic zone A) are presented in Table 5 and the night time cooling degree days are presented in Table 6.The weather analysis of the three climatic zones shows that in all areas there will be an increase in the cooling degree days and a decrease in the heating degree days, predicting an increase in the cooling energy demand and decrease in the heating energy demand. Iraklio (zone A) has the maximum number of night cooling degree days, the highest values of solar radiation and wind speed at present and in the future and presents the smallest diurnal differences. On the other hand, Thessaloniki (zone C) presents the maximum number of heating degree days along with the lowest values of solar radiation. Patra (zone B) has the maximum cooling degree days and large diurnal differences (Figure 7). Also in all areas, relative humidity is increasing with the years. Thessaloniki is the most humid city during the winter and spring months apart from the months May-August when Patra is the most humid area.

\section{Simulation results}

\subsection{Impact of the climate change on hotel building for the period 1970 - 2010}

Figure 8 and Figure 9 show the heating and cooling load of the demonstration hotel for the period $1970-2010$ when using real monitored data for the area of Athens. The simulation results show an increase of the cooling load of the hotel building by $33 \%$ and a decrease in the heating demand by $22 \%$ in 2010 compared to 1970 .

\subsection{Impact of the climate change on the hotel building using future files} 2020, 2050 and 2080

Using generated future files for the area of Patra, results indicate an increase of the cooling load of the building by $15 \%$ in year 2020, 34\% in year 2050 and $63 \%$ in year 2080. On the other hand heating load is expected to decrease by $14 \%$ in year $2020,29 \%$ in year 2050 and $46 \%$ in year 2080 (Table 7). 


\section{Mitigation strategies for an optimum building envelope design}

In order to tackle the climate change, a number of energy efficient techniques are studied for each climatic period. The energy efficient strategies that are studied for the hotel building are based on the example given in CIBSE TM36 (Hacker et al., 2005) and are summarised in Table 8.

Five principles are used to tackle the energy increase and overheating of the hotel: 'switch off', 'absorb', 'reflect', 'blow away' and 'convect'. The principle 'switch off' is realized with the control of solar gains in the interior of the building, with the use of external shading and the use of energy efficient glazing. The 'switch off \& absorb' principle is approached with the addition of external insulation in the non-insulated fabric. Energy efficient glazing summarizes both principles 'switch off' and reflect' by removing and 'reflecting' the undesirable solar gains. Apart from the glazing, the 'reflect' option is also illustrated by increasing the reflectance of the external surfaces and relieving indoor spaces from excessive peak temperatures. The 'blow away' principle is illustrated by an 'intelligent' ventilation system and the use of automated control in the daytime and nighttime ventilation according to the external temperature and the indoor temperature of each zone. In addition to the minimum airflow rates in each zone of the hotel as defined by the national legislation, extra fresh air is supplied in the areas of the hotel according to the external temperature and the internal temperature, both at day and night. The convection principle is illustrated with the use of ceiling fans by blowing the 'cool' air downwards to the occupied zone and extending the thermal comfort zone without the use of air conditioning. For every principle different scenarios are simulated as shown in Table 9, in order to define the most energy efficient ones.

\subsection{Mitigation strategies for climatic zone B}

Different scenarios in terms of insulation, glazing, shading, cool material and ventilation control are simulated in order to specify the most energy efficient techniques for the present day, period 2020, 2050 and 2080. The scenarios investigated are shown in Table 9, for example concerning insulation the following four scenarios are studied:

- Thickness of insulation so that the required U-values are obtained as defined by the current national EPBD legislation: Insulation $4 \mathrm{~cm}$ to the external walls and $7 \mathrm{~cm}$ to the roof $\left(\right.$ Uroof $=0.45 \mathrm{~W} / \mathrm{m}^{2} \mathrm{~K}$, Uwalls $\left.=0.5 \mathrm{~W} / \mathrm{m}^{2} \mathrm{~K}\right)$, 
- Thickness of insulation $7 \mathrm{~cm}$ to the external walls and roof, so that lower Uvalues are obtained $\left(\right.$ Uroof $=0.45 \mathrm{~W} / \mathrm{m}^{2} \mathrm{~K}$, Uwalls $=0.34 \mathrm{~W} / \mathrm{m}_{2} \mathrm{~K}$ )

- Thickness of insulation $10 \mathrm{~cm}$ to the external walls and roof $\left(\mathrm{Uroof}=0.32 \mathrm{~W} / \mathrm{m}^{2} \mathrm{~K}\right.$, Uwalls $\left.=0.25 \mathrm{~W} / \mathrm{m}^{2} \mathrm{~K}\right)$

- Thickness of insulation $12 \mathrm{~cm}$ to the external walls and roof $\left(\right.$ Uroof $=0.27 \mathrm{~W} / \mathrm{m}^{2} \mathrm{~K}$, Uwalls $\left.=0.21 \mathrm{~W} / \mathrm{m}^{2} \mathrm{~K}\right)$

The simulation results show that the highest energy savings are achieved when using $10 \mathrm{~cm}$ in the external walls and roof and that beyond this width, there is no extra benefit for the building.

Therefore, in terms of heating load, for the case of $10 \mathrm{~cm}$, the energy savings are 38 $\mathrm{kWh} / \mathrm{m}^{2} /$ year for the present climatic file (or $62 \%$ ), $33 \mathrm{kWh} / \mathrm{m}^{2} /$ year for year 2020 (or $64 \%$ ), $28 \mathrm{kWh} / \mathrm{m}^{2} /$ year for year 2050 (or $66 \%$ ) and $23 \mathrm{kWh} / \mathrm{m}^{2} /$ year for year 2080 (or $69 \%)$.

As expected adding insulation has little effect on the cooling load. Simulation results show a $6 \%$ increase in the present climatic file, $3 \%$ increase in year 2020, whereas a slight reduction of cooling demand by $1 \%$ is noted for year 2050 and $4 \%$ reduction for year 2080 .

The same analysis has been followed for the different scenarios of glazing, shading, ventilation control, and based on the simulations results it is found that different strategies can be applied to all year and seasonally operated buildings for the most energy efficient performance. These are summarized below:

- All year operated building.

The selected principles and energy techniques are those that have the best benefit for the building for both the heating and cooling period. The optimum buildings with all year operation comprise: Insulation $(10 \mathrm{~cm})$ in external walls and roof, double low e glazing $\left(\mathrm{U}=1.8 \mathrm{~W} / \mathrm{m}^{2} \mathrm{~K}, \mathrm{~g}=0.45\right)$, intelligently controlled night ventilation, intelligently controlled day ventilation, ceiling fans in the rooms, and shading to the corridors. The optimum building for present day and the optimum building for year 2020 comprise the same energy techniques. The optimum building for year 2050 comprises more shading. The optimum building for year 2080 includes even more shading and is also equipped with cool materials on the walls. The energy efficient strategies for each period are shown in Table 14. The heating and cooling load of the optimum buildings based on the simulation results are shown in Table 10. 
- Seasonally operated building.

In that case the building is operating during the months May to September. The simulations are carried out for the whole year but heating, cooling, ventilation and all internal gains (lighting, people) are operating only for the months May - September whereas for the months January - April and October to December the systems and internal gains are set to 0 . The 'optimum' buildings comprise: Intelligently controlled night ventilation, cool materials, ceiling fans, intelligently controlled day ventilation, shading and double low e glazing. The optimum building for the present day and year 2020 comprise the same energy techniques. The optimum building for year 2050 differs in the type of night ventilation control. The optimum building for year 2080 requires adequate thickness of insulation. The energy efficient strategies for each period are shown in Table 15. The heating and cooling loads of the optimum buildings based on the simulation results are shown in Table 11.

\subsection{Effectiveness of the proposed measures in different climatic zones}

The effectiveness of the proposed measures as these are selected for climatic zone B is investigated for climatic zones $\mathrm{A}$ and $\mathrm{C}$. For the purposes of the research the demonstration hotel (optimum building) is 'transposed' to the locations of Thessaloniki (climatic zone C) and Iraklio -island of Crete (climatic zone A).

The optimum building is equipped with the most energy efficient techniques (for present day and for years 2020, 2050 and 2080) as these are described in section 6.2 and shown in Table 14 and Table 15. The simulations results when transposing the optimum buildings of climatic zone B to climatic zones A and C are shown in Table 12 (for an all year operated building) and Table 13 (for a seasonally operated building). It is shown that more cooling is required in climatic zone A thus energy efficient strategies to be considered should include more shading and materials of high reflectance like glazing and external coatings for the building envelope. On the other hand, optimum building in climatic zone $\mathrm{C}$ requires extra insulation and materials to prevent heat losses.

\section{Discussion}

The climate change has various impacts on the environment, the society and the global economy. At the building level, the increase of the air temperature is linked to the increase of the building energy consumption and specifically to the increase of energy consumption for cooling in the Mediterranean countries like Spain, Italy and Greece. 
Using real monitored data for the period $1970-2010$, due to the increase of the air temperature the simulation results show an increase of the cooling load of the demonstration hotel by $33 \%$ and a decrease in the heating demand by $22 \%$.

As a response to the climate change, the most energy efficient adaptation methods are applied to the hotel building in climatic zone B, in an effort to identify the 'optimum' buildings for the present year, year 2020, year 2050 and year 2080. The climate change adaptation methods focus on the building envelope and are described by the following principles: 'blow away (intelligently controlled night and day ventilation), 'switch off; (shading), reflect (cool materials) 'reflect and switch off' (double low e glazing), 'switch off \& absorb' (insulation), and 'absorb' (thermal mass). Then the hotel is transposed to climatic zones $\mathrm{A}$ and $\mathrm{C}$ in order to assess the effectiveness of the selected measures in other locations with different climatic characteristics.

It should be noted that the main objective of this work is to identify the optimal refurbishment strategy given the constraints of the existing case-study building when exposed to different climatic conditions in Greece; for this reason obvious energy advantages due to building orientation and building form have not been explored. Furthermore, the building design of the demonstration hotel is not compatible with the principles of a bioclimatic and energy efficient architecture: all rooms face towards the sea despite the view's north orientation, the building form consists of a long rectangular shape, the north facing common areas have extended glazing areas and the openings of the circulation areas (corridors) facing south are not shaded It could be argued that the north orientation of the common areas and the extended glazing facing north enhances the passive cooling of these areas since the hotel is operating during the summer period; but in general, the building design of the demonstration hotel does not take into consideration optimum orientation, energy issues, comfort and heat exchange with the environment. It focuses on "architectural" parameters like the view, and this can be explained because its construction dates back in the 1970s thus in a period when the need for energy efficient building design was not compulsory.

The current study takes as default the building layout of the demonstration hotel, although this is not an optimum one in terms of orientation and form. In another circumstances and following a low energy design process, the building should be carefully sited in the different climatic zones and its building elements and form should be selected optimally in order to control, collect and store the sun's energy; resulting in another building design in climatic zones $\mathrm{A}, \mathrm{B}$ and $\mathrm{C}$. Therefore, for the purposes of this 
study, the building having the same orientation and design is hypothetically transposed to climatic zones $\mathrm{A}$ and $\mathrm{C}$.

The adaptation methods are applied in two modes of buildings: a. all year operated, and b. seasonally operated (operating the months May-September). The aim of this distinction is to investigate whether the building owners can focus on specific adaptation methods according to the operation of their building and understand which investments have a long term benefit.For an 'all year' operated building the mitigation strategies focus on both the heating and cooling period in order to reduce heat transfer during winter and switch off the solar gains during summer, whereas for a seasonally operated building, the mitigation strategies focus on the cooling period in order to remove excessive solar gains. A different hierarchy is noted in the selection of the mitigation strategies for an 'all year' operated and 'seasonally' operated building.

All year operated building: For an 'all year operated' building, the principle 'switch off \& absorb' (insulation) is the one with the most savings in the heating period. The simulations show that a width of insulation greater than $10 \mathrm{~cm}$ does not provide additional benefit to the energy demand of the building. The 'blow away' principle (intelligently controlled night ventilation) is the second measure to invest on and results in the highest savings in the cooling period. Among the controls of night ventilation that were investigated (Table 9) the one that performs at indoor temperature $>23^{\circ} \mathrm{C}$ results in the highest energy savings in both the heating and cooling period. Then the third principle to be considered is the 'reflect and switch off' illustrated by the use of energy efficient glazing that lowers the energy demand; a configuration of U-value $1.00 \mathrm{~W} / \mathrm{m}^{2} \mathrm{~K}$ and $g=0.55$ results in the highest energy savings for both the heating and cooling period. The technique of intelligently controlled day ventilation is the fourth principle in the hierarchy that reduces the cooling load significantly but has a much lower impact on the heating load. Among the controls of day time ventilation the one that performs at indoor temperature of each zone $>23^{\circ} \mathrm{C}$ and indoor temperature $>$ outdoor temperature results on the highest energy savings for both the heating and cooling period.

The shading technique ('switch off' principle) is also playing an important role for the reduction of cooling load. However, for the specific building, this technique does not result in huge energy savings because of the northern orientation of the large area of the openings. Finally, the 'reflect' principle illustrated by the use of cool materials results in reduction of the cooling load but this is offset by significant increase of the heating load. The use of cool materials starts to be of clear benefit for the building after year 
2080 where the difference between the decrease of the cooling load and the increase of the heating load becomes small. Therefore the use of cool materials is recommended for the optimum building of year 2080. Ceiling fans are also suggested for a building with all year operation as their use has a significant impact on the cooling load and no impact on the heating load.

However, because of the air temperature increase the optimum building of year 2080 still presents the highest cooling load compared to the optimum buildings of the other climatic periods. Therefore for year 2080, with the application of conventional energy efficient strategies, $175 \%$ ( or $14 \mathrm{kWhkWh} / \mathrm{m}^{2} / \mathrm{yr}$ ) more cooling will be required compared to the present day (Table 10).

Seasonally operated building: Concerning a hotel with seasonal operation (months May - September), the optimum energy measures are those that achieve the maximum reduction in the cooling load. The most important principle to be implemented is the 'blow away', represented by the use of intelligently controlled night ventilation that results in significant energy savings for the cooling period. The simulations show that slight different results are achieved according to the ventilation control. Therefore, for the present day climate file and year 2020 the maximum energy savings in the area of night ventilation occur when night ventilation performs at outdoor temperature greater than $15^{\circ} \mathrm{C}$, whereas for the years 2050 and 2080 the maximum energy savings are achieved when night ventilation performs at indoor temperature $>$ $23^{\circ} \mathrm{C}$. This can be explained by the increase of the air temperature.

The 'reflect principle' with the use of cool materials is the second technique in the hierarchy, followed by the 'convection' principle (ceiling fans), the 'blow away' technique (intelligently controlled day ventilation), the 'switch off' principle (shading) and the 'reflect \& switch off' principle (glazing, with a U-value of $1.8 \mathrm{~W} / \mathrm{m}^{2} \mathrm{~K}$ and $\mathrm{g}=0.45)$. The 'switch off $\&$ absorb' principle illustrated by the use of insulation favors the heating period and has a negative impact on the cooling period for the present day file, and the climate files 2020 and 2050. However, the simulation shows a positive impact of this technique on the cooling load for year 2080 and thus is recommended only for the optimum building in year 2080. Although the significant reduction of the cooling load due to the upgrade of the building fabric, the optimum building of year 2080 will require $217 \%$ (or $13 \mathrm{kWhkWh} / \mathrm{m}^{2} / \mathrm{yr}$ ) more cooling from the current situation (Table 11). 
The simulations of the energy techniques in the different climatic zones show that optimum buildings in Iraklio (climatic zone A) present the highest cooling energy demand, whereas optimum buildings in Thessaloniki (climatic zone C) present the highest heating energy demand. From the climatic analysis, it seems that Patra (climatic zone B) presents maximum cooling degree days, large diurnal differences and small night time temperatures. As a result, during the year, Patra is cooler than Iraklio, and presents the mildest climatic characteristics, compared to Thessaloniki and Iraklio. As the most energy efficient techniques were selected for the optimum buildings in climatic zone (B), it seems that in terms of cooling the techniques are performing very well for buildings in Thessaloniki (that is cooler area than Patra) but not so well for buildings in Iraklio that in overall is warmer area than Patra. Therefore, the optimum buildings in Thessaloniki present nearly zero cooling load, ranging from $4 \mathrm{kWh} / \mathrm{m}^{2} / \mathrm{yr}$ in present year to $14 \mathrm{kWh} / \mathrm{m}^{2} / \mathrm{yr}$ in year 2080 (Table 12). However in areas as Iraklio with higher night time temperatures and solar radiation than Patra, optimum buildings present quite high energy demand for cooling, ranging for the 'all year' operated building from 10 $\mathrm{kWh} / \mathrm{m}^{2} / \mathrm{yr}$ (present) to $29 \mathrm{kWh} / \mathrm{m}^{2} / \mathrm{yr}$ (year 2080), (Table 12) and for the 'seasonally' operated building from $6 \mathrm{kWh} / \mathrm{m}^{2} / \mathrm{yr}$ (present) to $24 \mathrm{kWh} / \mathrm{m}^{2} / \mathrm{yr}$ (year 2080), (Table 13). For this area and especially for the long term future (2080) more drastic climate change solutions are required; the development of a design strategy based on the principles 'switch off', 'reflect' and 'blow away' would help the removal of solar gains and excessive heat gains. This strategy could include even more shading, different type of glazing (reflecting), cool materials of better performance and probably exploitation of the wind patterns of the area with another strategy/control of daytime and nighttime ventilation.

In terms of heating load, the optimum buildings in areas colder than Patra with more HDD, i.e.Thessaloniki, are not well equipped with the specific mitigation strategies and require high energy demand that ranges between $58 \mathrm{kWh} / \mathrm{m}^{2} / \mathrm{yr}$ in present to $41 \mathrm{kWh} / \mathrm{m}^{2} / \mathrm{yr}$ in year 2080 (Table 12). A design strategy based on the 'switch off and absorb' principle would provide higher level of insulations, combined with a more appropriate glazing that would prevent heat losses, the minimization of shading and the avoidance of cool materials. On the other hand, the optimum buildings of areas with less HDD than Patra, i.e. Iraklio, would present almost zero heating energy demand in 2080 . 
The climatic analysis of the forecast future years shows that the decrease in heating degree days is almost double than the increase of the cooling degree days. This results in an increase of the cooling demand and decrease of the heating demand in the future. Taking into consideration that cooling mainly relies on electricity; this signifies a modification on the use of the primary energy and a shift towards electrical power. Other alternatives like renewable energy source should be considered for the generation of electrical energy.

The simulations were performed taking into consideration current conventional mitigation measures, thus passive cooling techniques that focus on the upgrade of the building envelope and deal with the control of heat transfer (switch off and absorb principle), solar control (switch off and reflect principle), heat gain (thermal storage capacity, absorb principle), heat dissipation (blow away principle) and the adjustment of the cooling set point (convection principle). With the implementation of the above climate change adaptation methods a significant reduction of the building energy demand is achieved in both the cooling and heating season but still the building presents rather high cooling in the long term future. This may indicate the inefficiency of the conventional mitigation methods to cope with the climate change and the necessity to develop further the technical characteristics of the current technologies to cope with severe climatic characteristics, in the long term future.

\section{Conclusions}

The study has investigated climate change mitigation strategies for an optimum building envelope design for a hotel building in Greece for the current year, and years 2020, 2050 and 2080. The adaptation strategies are assessed for two modes of operation: 'all year' operated building and 'seasonally' operated building. The efficiency of the proposed strategies is assessed for the 3 climatic regions of Greece, A, B and C. The whole assessment is performed via hourly simulations using the TRNSYS software.

The climate change and in particular the increase of the air temperature has a significant impact on the energy demand for cooling of the hotel building. Using real monitored data for the period $1970-2010$ for the area of Athens an increase of the cooling load (33\% in 2010 compared to 1970) and a decrease of the heating load (22\% in 2010 compared to 1970). 
Future files were generated for the period 2020, 2050 and 2080 using the CCWorldWeather Generator tool developed by Southampton University (Southampton University,2010; Jentsch et al., 2008). The simulation results indicate an increase of the cooling load of the demonstration hotel building by $15 \%$ in year $2020,34 \%$ in year 2050 and $63 \%$ in year 2080. On the other hand heating load is expected to decrease by $14 \%$ in year 2020, 29\% in year 2050 and $46 \%$ in year 2080 .

Climate change mitigation strategies including insulation, glazing, ventilation, cool materials and shading are investigated for the hotel building for climatic areas A, B and $\mathrm{C}$ of Greece for an optimum building design. Between the three climatic areas, the optimum buildings require more cooling in climatic zone $\mathrm{A}$ and extra mitigation strategies are in need based on the principles 'switch off' (shading), 'reflect'(reflective glazing and cool materials on external surface) and 'blow away' (day time and nighttime ventilation control) to cope with the increased solar gains. In terms of heating, the optimum buildings in climatic zone $\mathrm{C}$ require extra mitigation strategies based on the 'switch off and absorb' principle (insulation) to cope with the heat losses through the building envelope.

Hotels are distinguished in 'all year' operated and 'seasonally' operated buildings. The aim of this distinction is to investigate whether the building owners can focus on specific adaptation methods according to the operation of their building and understand which investments have a long term benefit.

For an 'all year' operated building the mitigation strategies focus on both the heating and cooling period in order to reduce heat transfer during winter and switch off the solar gains during summer, whereas for a seasonally operated building, the mitigation strategies focus on the cooling period in order to remove excessive solar gains.

It is found that different strategies can be applied to all year and seasonally operated buildings for the most energy efficient performance. For an all year operated building, the implementation of insulation offers the highest energy savings in the heating period whereas the use of intelligently controlled night ventilation results in the highest savings in the cooling period. The use of cool materials and extra shading is required for buildings of the long term future, i.e for year 2080.

For a seasonally operated building, the most important principle to be implemented is the use of intelligently controlled night ventilation that results in significant energy savings for the cooling period. The implementation of insulation is recommended only for the optimum building projected in year 2080 . 
The simulation results show that the cooling load of the 'optimum' buildings are rather high in 2050 and 2080, meaning that the current technologies are not efficient enough to cope with the climate change in the long term future. Additionally, in terms of heating, optimum buildings are not very efficient in areas with severe climatic conditions. Taking into consideration that currently cooling is provided mainly by electricity, there will be a huge increase of the fuel's demand thus for a better performance the energy efficient building envelope design should be combined with the use of energy efficient plant.

\section{References}

Avgelis A., Papadopoulos A.M. (2009): 'Application of multicriteria analysis in designing HVAC systems', Energy and Buildings, Volume 41 (7):774-780

Belcher, SE, JN Hacker, and DS Powell (2005): 'Constructing design weather data for future climates'. BUILDING SERV ENG RES TECHNOL 26:49. doi:10.1191/0143624405bt112oa.

Cartalis, C, SynodinouA., ProedrouM., Tsangrassoulis A., and Santamouris M. (2001): 'Modifications in energy demand in urban areas as a result of climate changes: an assessment for the southeast Mediterranean region'. Energy Conversion and Management 42 (14): 1647-1656. doi:10.1016/S0196-8904(00)00156-4.

Chan, A.L.S. (2011): 'Developing future hourly weather files for studying the impact of climate change on building energy performance in Hong Kong'. Energy and Buildings 43 (10): 2860-2868. doi:10.1016/j.enbuild.2011.07.003.

Chan, A.L.S. (2011):'Developing a modified typical meteorological year weather file for Hong Kong taking into account the urban heat island effect'. Building and Environment 46: 2434-2441

CIBSE TM36 :2005, 'Climate Change and the indoor environment: impacts and adaptation' 
CIBSETM41:2006, Degree-days: theory and application.

Committee for the Study of the Climate Change Impact.(2011), 'Environmental, financial and social consequences of climate change in Greece'.

Eames, M., T. Kershaw, and D. Coley.(2012), 'A comparison of future weather created from morphed observed weather and created by a weather generator'. Building and Environment 56: 252-264. doi:10.1016/j.buildenv.2012.03.006.

European Environment Agency.(2004), 'Impact of Europe 's changing climate'.

Frank, Th. (2005), 'Climate change impacts on building heating and cooling energy demand in Switzerland'. Energy and Buildings 37 (11): 1175-1185.

Giannakidis, G., AsimakopoulosD.A., SantamourisM, FarrouI., LaskariM., SaliariM., ZanisG., et al.(2011), 'Modelling the energy demand projection of the building sector in Greece in the 21st century'. In Press.

Giannakopoulos, Ch., HadjinicolaouP., ZerefosCh., and DemosthenousG.(2009), 'Changing Energy Requirements in the Mediterranean Under Changing Climatic Conditions'. Energies 2: 805-815.

Guan, L. (2009), 'Preparation of future weather data to study the impact of climate change on buildings'. Building and Environment 44 (4): 793-800. doi:10.1016/j.buildenv.2008.05.021.

Guan, L.(2012), 'Energy use, indoor temperature and possible adaptation strategies for air-conditioned office buildings in face of global warming'. Building and Environment 55: 8-19. doi:10.1016/j.buildenv.2011.11.013.

Hacker, J., M. Holmes, S. Belcher, and G. Davies. 2005. 'CIBSE TM36:2005 Climate change and the indoor environment: impacts and adaptation'. 
Hassid,SantamourisM., PapanikolaouN., LinardiA., N. KlitsikasN., Georgakis C., Assimakopoulos D.N. (2000): 'The Effect of the Athens Heat Island on Air Conditioning Load', J. Energy and Buildings, 32,2,131-141.

IPPC, Intergovermental Panel on climate change. (2011), 'IPPC Special Report on Renewable Energy Sourves and Climate Change Mitigation, Final Release'.

Jentsch, M.F. (2010), 'Climate Change Weather File Generators. Technical reference manual for the CCWeatherGen and CCWorldWeatherGen tools'.

Jentsch, Mark F., AbuBakr S.Bahaj, and Patrick A.B. James (2008), 'Climate change future proofing of buildings - Generation and assessment of building simulation weather files'. Energy and Buildings 40 (12): 2148-2168. doi:10.1016/j.enbuild.2008.06.005.

Kapsomenakis, KolokotsaD., NikolaouT., SantamourisM., andZerefosS. C. (2013): 'FortyYearsIncreaseof the Air Ambient Temperature in Greece: The Impact on Buildings', EnergyConversionand Management, 74: 353-365

Kolokotroni, M., Zhang, Y. Watkins, R., (2007):'The London heatislandandbuildingcooling design'. Solar Energy 81, 102-110.

Kolokotroni, M., X. Ren, M. Davies, and A. Mavrogianni. (2012):'London 's urban heat island: Impact on current and future energy consumption in office buildings'. Energy and Buildings 47: 302-311. doi:10.1016/j.enbuild.2011.12.019.

Kolokotroni, GowreesunkerB.L., Giridharan R.(2013): 'Cool roof technology in London: An experimental and modelling study' Original Research Article Energy and Buildings, Volume 67: 658-667

Mastrapostoli E.; Karlessi Th.; Pantazaras Al.; Gobakis K.; Kolokotsa D.; Santamouris M. (2014): 'On the cooling potential of cool roofs in cold climates: Use of cool 
fluorocarbon coatings to enhance the optical properties and the energy performance of industrial buildings', Energy and Buildings 69: 417-425

Mavromatidis L., Mohamed El Mankibi, Pierre Michel, Bykalyuk A., Santamouris M.(2012) : 'Guidelines to study numerically and experimentally reflective insulation systems as applied to buildings', Advances in Building Energy Research.

Ouedraogo, B.I., G.J. Levermore, and J.B. Parkinson.(2012): 'Future energy demand for public buildings in the context of climate change for Burkina Faso'. Building and Environment 49: 270-282. doi:10.1016/j.buildenv.2011.10.003.

Oxizidis, S., DudekA.V., and PapadopoulosA.M.(2008): 'A computational method to assess the impact of urban climate on buildings using modelled climatic data'. Energy and Buildings 40 (3): 215-223. doi:10.1016/j.enbuild.2007.02.018.

Papadopoulos A.M.(2005): 'State of the art in thermal insulation materials and aims for future developments' Original Research Article Energy and Buildings37 (1):77-86

Robert A., Kummert M., (2012):'Designing net zero-energy buildings for the future climate, not for the past'.Building and Environment 55: 150-158. doi:10.1016/j.buildenv.2011.12.014

Santamouris M, N. Papanikolaou, I. Livada, I. Koronakis, C. Georgakis, A. Argiriou and D. N. Assimakopoulos(2001): 'On the Impact of Urban Climate to the Energy Consumption of Buildings' Solar Energy 70 (3): 201-216

Santamouris M , SynnefaA., KarlessiT.(2011): 'Using advanced cool materials in the urban built environment to mitigate heat islands and improve thermal comfort conditions' Solar Energy 85: 3085-3102 
Santamouris M. (2012): 'Cooling the cities - A review of reflective and green roof mitigation technologies to fight heat island and improve comfort in urban environments', Solar Energy

Santamouris M, GaitaniN., SpanouA., SaliariM., GianopoulouK. and VasilakopoulouK. (2012b): 'Using Cool Paving Materials to Improve Microclimate of Urban Areas Design Realisation and Results of the Flisvos Project'. Building and Environment 53: $128-136$

Santamouris M, Kolokotsa D. (2013): 'Passive cooling dissipation techniques for buildings and other structures: The state of the art Review Article, Energy and Buildings 57: 74-94.

Southampton University.(2010): 'Manual, CCWorldWeatherGen Climate change world weather File generator'.

Synnefa A., Saliari M., Santamouris M. (2012): 'Experimental and numerical assessment of the impact of increased roof reflectance on a school building in Athens Original Research Article Energy and Buildings55: 7-15

Technical Chamber of Greece 20701-1/. (2010): 'Technical Directive - Technical Chamber of Greece T.O.T.E.E. 20701-1/2010 Analytical Specifications of Parameters for the calculation of the Energy Performance of Buildings and the issue of Energy Certificate'.

Technical Chamber of Greece 20701-3/. (2010):'Technical Directive - Technical Chamber of Greece T.O.T.E.E. 20701-3/2010 Climatic Data of Greek Regions'.

Tselepidaki, I., M. Santamouris, D.N. Asimakopoulos, and S. Kontoyiannidis.(1994):

'On the variability of cooling degree-days in an urban environment: application to Athens, Greece'. Energy and Buildings 21 (2): 93-99. doi:10.1016/03787788(94)90002-7. 
Wan, Kevin K.W., Danny H.W. Li, Dalong Liu, and Joseph C. Lam. (2011): 'Future trends of building heating and cooling loads and energy consumption in different climates'. Building and Environment 46 (1): 223-234.

doi:10.1016/j.buildenv.2010.07.016.

Wan, Kevin K.W., Danny H.W. Li, Wenyan Pan, and Joseph C. Lam. (2012): 'Impact of climate change on building energy use in different climate zones and mitigation and adaptation implications'. Applied Energy 97: 274-282.

doi:10.1016/j.apenergy.2011.11.048.

Xu, Peng, Yu Joe Huang, Norman Miller, Nicole Schlegel, and Pengyuan Shen.(2012): 'Impacts of climate change on building heating and cooling energy patterns in California'. Energy 44 (1): 792-804. doi:10.1016/j.energy.2012.05.013. 


\section{LIST OF TABLES}

Table 1: U-values of the building elements that are considered in the simulations

Table 2: Building systems of the hotel building

Table 3: Shading factors calculated according to the Technical Guidelines TOTEE 20701-1/2010

Table 4: Mean degree hours for the area of Athens for the period 1970-2010

Table 5: Cooling and heating mean degree hours for Patra, Iraklio and Thessaloniki, for present climatic file and years 2020, 2050 and 2080

Table 6: Night-time cooling degree days for Patra, Iraklio and Thessaloniki, for present climatic file and years 2020, 2050 and 2080

Table 7: Heating and cooling load $\left(\mathrm{kWh} / \mathrm{m}^{2} / \mathrm{yr}\right)$ for the hotel building for the years 2020, 2050 and 2080

Table 8: Climate change mitigation strategies for the hotel building

Table 9: Energy efficient techniques for the upgrade of the building envelope of the demonstration hotel as a response to the climate change

Table 10: Heating and cooling loads $\left(\mathrm{kWh} / \mathrm{m}^{2} / \mathrm{yr}\right)$ for the optimum building with all year operation

Table 11: Heating and cooling loads $\left(\mathrm{kWh} / \mathrm{m}^{2} / \mathrm{yr}\right)$ for the optimum building with seasonal operation

Table 12: Heating and cooling loads for the 'all year operated' optimum buildings for the 3 climatic zones

Table 13: Heating and cooling loads for the 'seasonally operated' optimum buildings for the 3 climatic zones 
Table 2: U-values of the building elements that are considered in the simulations

\begin{tabular}{|c|c|c|}
\hline $\begin{array}{l}\text { Building element - U-value } \\
\qquad\left(\mathrm{W} / \mathbf{m}^{2} \mathrm{~K}\right)\end{array}$ & $\begin{array}{l}\text { Typical U values for } \\
\text { constructions before } \\
\text { 1979 TOTEE 20701- } \\
\text { 1/2010 ppg 46/47) }\end{array}$ & $\begin{array}{l}\text { Required U-value (TOTEE } \\
\text { 20701-1/2010) for climatic } \\
\text { zone B (ppg } 43 \text { table } 3.3 a)\end{array}$ \\
\hline $\begin{array}{l}\text { External wall: Plaster - brick - plaster, with } \\
\text { plaster externally \& internally }\end{array}$ & 2.20 & 0.50 \\
\hline $\begin{array}{l}\text { External wall-concrete frame, with plaster } \\
\text { externally \& internally }\end{array}$ & 3.40 & 0.50 \\
\hline Roof: Plaster - concrete - plaste & 3.05 & 0.45 \\
\hline Floor (concrete slab) to external air & 2.75 & 0.45 \\
\hline Ground floor : concrete slab & 3.10 & 0.90 \\
\hline Windows (glazing \& frame) & & \\
\hline Common areas: single with aluminum frame & $\begin{array}{l}\text { Ugl:5.68 } \\
\text { Ufr: } 7.00 \\
\end{array}$ & 3.00 \\
\hline $\begin{array}{l}\text { Corridors to the rooms (facing south): } \\
\text { double with aluminum frame }\end{array}$ & $\begin{array}{l}\text { Ugl: } 2.95 \\
\text { Ufr: } 7.00\end{array}$ & 3.00 \\
\hline Rooms: single with wooden frame & $\begin{array}{l}\text { Ugl:5.68 } \\
\text { Ufr: } 2.20 \\
\end{array}$ & 3.00 \\
\hline Infiltration & \multicolumn{2}{|c|}{$\begin{array}{l}\text { 0.44ach (according to the Technical Guidelines TOTEE } \\
\text { 20701-1/2010) }\end{array}$} \\
\hline
\end{tabular}

Table 2: Building systems of the hotel building

\begin{tabular}{|l|l|}
\hline \multicolumn{2}{|c|}{ Building systems of the hotel building } \\
\hline Heating & $\begin{array}{l}\text { Central heating is with gas via radiators and operates in the rooms and the common } \\
\text { areas of the hotel. Central heating operates occasionally during the heating period, when } \\
\text { the hotel is open, i.e. during the Christmas period. (Design temperature } 20^{\circ} \mathrm{C} \text { ) }\end{array}$ \\
\hline Cooling & $\begin{array}{l}\text { A/C split units in each room. There is no cooling in the common areas. (Design } \\
\text { temperature } 26^{\circ} \mathrm{C} \text { ) }\end{array}$ \\
\hline Ventilation & $\begin{array}{l}\text { All areas of the hotel are naturally ventilated via openable windows. No mechanical } \\
\text { ventilation is installed in the main areas of the hotel. }\end{array}$ \\
\hline DHW & Flat plate solar collectors are used for DHW \\
\hline Airflow rates & $\begin{array}{l}\text { Common areas: } 9 \mathrm{~m}^{3} / \mathrm{h} / \mathrm{m}^{2}, \text { Rooms: } 1.2 \mathrm{~m}^{3} / \mathrm{h} / \mathrm{m}^{2} \text { (according to the Technical Guidelines } \\
\text { TOTEE } 20701-1 / 2010)\end{array}$ \\
\hline
\end{tabular}

Table 3: Shading factors calculated according to the Technical Guidelines TOTEE 20701-1/2010

\begin{tabular}{|l|c|c|c|c|}
\hline \multicolumn{5}{|c|}{ Shading factor (according to the Technical Guidelines TOTEE 20701-1/2010) } \\
\hline Rooms & $1^{\text {st }}$ and $2^{\text {nd }}$ floor & 3rd and $4^{\text {nd }}$ floor & $2.85 \mathrm{~m}$ height & $3.75 \mathrm{~m}$ height \\
\hline $\begin{array}{l}\text { Windows } \\
\text { southeast }\end{array}$ & 0.43 & 0.14 & & \\
\hline $\begin{array}{l}\text { Windows } \\
\text { northwest }\end{array}$ & & & 0.28 & 0.2 \\
\hline
\end{tabular}


Table 4: Mean degree hours for the area of Athens for the period 1970-2010

\begin{tabular}{|c|c|c|c|c|c|c|c|c|c|c|c|}
\hline \multicolumn{10}{|c|}{ Mean degree hours for the area of Athens } \\
\hline & CDD & HDD & & CDD & HDD & & CDD & HDD & & CDD & HDD \\
\hline $\mathbf{1 9 7 0}$ & 128 & 1159 & $\mathbf{1 9 8 1}$ & 124 & 1101 & $\mathbf{1 9 9 1}$ & 153 & 1261 & $\mathbf{2 0 0 1}$ & 282 & 996 \\
\hline $\mathbf{1 9 7 1}$ & 118 & 1178 & $\mathbf{1 9 8 2}$ & 122 & 1273 & $\mathbf{1 9 9 2}$ & 191 & 1189 & $\mathbf{2 0 0 2}$ & 223 & 1032 \\
\hline $\mathbf{1 9 7 2}$ & 139 & 1120 & $\mathbf{1 9 8 3}$ & 87 & 1260 & $\mathbf{1 9 9 3}$ & 276 & 1013 & $\mathbf{2 0 0 3}$ & 281 & 1217 \\
\hline $\mathbf{1 9 7 3}$ & 160 & 1127 & $\mathbf{1 9 8 4}$ & 95 & 1156 & $\mathbf{1 9 9 4}$ & 201 & 1069 & $\mathbf{2 0 0 4}$ & 184 & 1099 \\
\hline $\mathbf{1 9 7 4}$ & 136 & 1134 & $\mathbf{1 9 8 5}$ & 145 & 1093 & $\mathbf{1 9 9 5}$ & 200 & 1145 & $\mathbf{2 0 0 5}$ & 196 & 1161 \\
\hline $\mathbf{1 9 7 5}$ & 68 & 1171 & $\mathbf{1 9 8 6}$ & 169 & 1067 & $\mathbf{1 9 9 6}$ & 165 & 1171 & $\mathbf{2 0 0 6}$ & 234 & 1242 \\
\hline $\mathbf{1 9 7 6}$ & 162 & 996 & $\mathbf{1 9 8 7}$ & 203 & 1234 & $\mathbf{1 9 9 7}$ & 275 & 1098 & $\mathbf{2 0 0 7}$ & 313 & 1052 \\
\hline $\mathbf{1 9 7 7}$ & 114 & 1082 & $\mathbf{1 9 8 8}$ & 222 & 1180 & $\mathbf{1 9 9 8}$ & 262 & 914 & $\mathbf{2 0 0 8}$ & 308 & 1026 \\
\hline $\mathbf{1 9 7 8}$ & 131 & 1024 & $\mathbf{1 9 8 9}$ & 133 & 1139 & $\mathbf{1 9 9 9}$ & 271 & 1023 & $\mathbf{2 0 0 9}$ & 209 & 954 \\
\hline $\mathbf{1 9 7 9}$ & 131 & 1138 & $\mathbf{1 9 9 0}$ & 190 & 993 & $\mathbf{2 0 0 0}$ & 153 & 1261 & $\mathbf{2 0 1 0}$ & 278 & 805 \\
\hline $\mathbf{1 9 8 0}$ & 128 & 1159 & & & & & & & & & \\
\hline
\end{tabular}

Table 5: Cooling and heating mean degree hours for Patra, Iraklio and Thessaloniki, for present climatic file and years 2020, 2050 and 2080

\begin{tabular}{|c|c|c|c|c|c|c|c|c|c|}
\hline \multicolumn{4}{|c|}{$\begin{array}{l}\text { Heating (base temp } 18^{\circ} \mathrm{C} \text { ) and } \\
\text { Cooling (base temp } 26^{\circ} \mathrm{C} \text { ) Degree } \\
\text { Days }\end{array}$} & \multicolumn{3}{|c|}{ Variation \% from present } & \multicolumn{3}{|c|}{ Variation in degree days } \\
\hline & Patra & Thes. & Iraklio & Patra & Thes. & Iraklio & Patra & Thes. & Iraklio \\
\hline \multicolumn{10}{|c|}{ Present } \\
\hline CCD & 169 & 141 & 122 & & & & & & \\
\hline HDD & 1121 & 2123 & 871 & & & & & & \\
\hline \multicolumn{10}{|c|}{2020} \\
\hline CCD & 200 & 177 & 159 & 19 & 25 & 31 & 32 & 36 & 38 \\
\hline HDD & 990 & 1961 & 753 & -12 & -8 & -13 & -130 & -162 & -118 \\
\hline \multicolumn{10}{|c|}{2050} \\
\hline CCD & 250 & 218 & 212 & 48 & 54 & 75 & 82 & 77 & 91 \\
\hline HDD & 851 & 1812 & 631 & -24 & -15 & -28 & -269 & -311 & -240 \\
\hline \multicolumn{10}{|c|}{2080} \\
\hline CCD & 330 & 289 & 302 & 96 & 104 & 149 & 161 & 147 & 181 \\
\hline HDD & 681 & 1607 & 478 & -39 & -24 & -45 & -440 & -517 & -393 \\
\hline
\end{tabular}

Table 6: Night-time cooling degree days for Patra, Iraklio and Thessaloniki, for present climatic file and years 2020, 2050 and 2080

\begin{tabular}{|c|c|c|c|c|c|c|c|c|c|}
\hline \multicolumn{4}{|c|}{$\begin{array}{c}\text { Night Cooling (base temp } 20^{\circ} \mathrm{C} \text { ) } \\
\text { Degree Days }\end{array}$} & \multicolumn{3}{|c|}{ Variation \% from present } & \multicolumn{3}{|c|}{ Variation in degree days } \\
\hline & Patra & Thes. & Iraklio & Patra & Thes. & Iraklio & Patra & Thes. & Iraklio \\
\hline \multicolumn{10}{|c|}{ Present } \\
\hline CCD & 101 & 64 & 143 & & & & & & \\
\hline \multicolumn{10}{|c|}{2020} \\
\hline CCD & 126 & 85 & 172 & 25 & 33 & 20 & 25 & 21 & 29 \\
\hline \multicolumn{10}{|c|}{2050} \\
\hline CCD & 157 & 109 & 211 & 55 & 70 & 48 & 56 & 45 & 68 \\
\hline \multicolumn{10}{|c|}{2080} \\
\hline CCD & 206 & 149 & 273 & 104 & 133 & 91 & 105 & 85 & 130 \\
\hline
\end{tabular}


Table 7: Heating and cooling load $\left(\mathrm{kWh} / \mathrm{m}^{2} / \mathrm{yr}\right)$ for the hotel building for the years 2020, 2050 and 2080

\begin{tabular}{|c|c|c|}
\hline & $\begin{array}{c}\text { Heating load } \\
\left(\mathbf{k W h} / \mathbf{m}^{\mathbf{2}} / \text { year }\right)\end{array}$ & $\begin{array}{c}\text { Cooling load } \\
\left(\mathbf{k W h} / \mathbf{m}^{\mathbf{2}} / \text { year }\right)\end{array}$ \\
\hline Present day & 61 & 41 \\
\hline $\mathbf{2 0 2 0}$ & 52 & 47 \\
\hline 2050 & 43 & 55 \\
\hline 2080 & 33 & 67 \\
\hline
\end{tabular}

Table 8: Climate change mitigation strategies for the hotel building

\begin{tabular}{|c|c|l|}
\hline Principle & Type of Principle & \multicolumn{1}{|c|}{ Techniques } \\
\hline switch off & Passive cooling & Shading, double low emission glazing \\
\hline absorb \& switch off & Passive cooling & adding insulation in walls \& roof \\
\hline Reflect & Passive cooling & cool materials \& double low e glazing \\
\hline blow away & Passive cooling & Intelligent night and day time control \\
\hline Convection & Hybrid cooling & using ceiling fans \\
\hline
\end{tabular}

Table 9: Energy efficient techniques for the upgrade of the building envelope of the demonstration hotel as a response to the climate change

\begin{tabular}{|c|c|c|}
\hline Principle & Technique & $\begin{array}{r}\text { Description } \\
\end{array}$ \\
\hline \multirow{4}{*}{$\begin{array}{l}\text { Absorb \& switch off- } \\
\quad \text { (insulation) }\end{array}$} & National legislation & $\mathrm{U}$ roof $=0.45 \mathrm{~W} / \mathrm{m}^{2} \mathrm{~K}$, Uwalls $=0.5 \mathrm{~W} / \mathrm{m}^{2} \mathrm{~K}$ \\
\hline & $7 \mathrm{~cm}$ & U roof $=0.45 \mathrm{~W} / \mathrm{m}^{2} \mathrm{~K}, \mathrm{Uwalls}=0.34 \mathrm{~W} / \mathrm{m}^{2} \mathrm{~K}$ \\
\hline & $10 \mathrm{~cm}$ & $\mathrm{U}$ roof $=0.32 \mathrm{~W} / \mathrm{m}^{2} \mathrm{~K}, \mathrm{Uwalls}=0.25 \mathrm{~W} / \mathrm{m}^{2} \mathrm{~K}$ \\
\hline & $12 \mathrm{~cm}$ & $\mathrm{U}$ roof $=0.27 \mathrm{~W} / \mathrm{m}^{2} \mathrm{~K}, \mathrm{Uwalls}=0.21 \mathrm{~W} / \mathrm{m}^{2} \mathrm{~K}$ \\
\hline \multirow{5}{*}{$\begin{array}{c}\text { Switch off \& reflect - } \\
\text { (glazing) }\end{array}$} & Double glazing & $\mathrm{U}=2.95 \mathrm{~W} / \mathrm{m}^{2} \mathrm{~K}, \mathrm{~g}=0.8$ \\
\hline & Double low $-\mathrm{e}$ & $\mathrm{U}=1.8 \mathrm{~W} / \mathrm{m}^{2} \mathrm{~K}, \mathrm{~g}=0.6$ \\
\hline & Double low e & $\mathrm{U}=1.8 \mathrm{~W} / \mathrm{m}^{2} \mathrm{~K}, \mathrm{~g}=0.45$ \\
\hline & Double low -e \& argon & $\mathrm{U}=1.43 \mathrm{~W} / \mathrm{m}^{2} \mathrm{~K}, \mathrm{~g}=0.6$ \\
\hline & Double low e & $\mathrm{U}=1.06 \mathrm{~W} / \mathrm{m}^{2} \mathrm{~K}, \mathrm{~g}=0.55$ \\
\hline \multirow{5}{*}{$\begin{array}{l}\text { Switch off - } \\
\text { (shading) }\end{array}$} & Shading to corridors & Shading factor 0.5 \\
\hline & Shading to corridors & Shading factor 0.7 \\
\hline & Shading to corridors & Shading factor 0.8 \\
\hline & Shading to corridors \& rooms & Shading factor $0.8 \& 0.5$ \\
\hline & Shading to corridors \& rooms & Shading factor $0.8 \& 0.7$ \\
\hline \multirow{2}{*}{$\begin{array}{c}\text { Reflect - } \\
\text { (cool materials) }\end{array}$} & External walls & Solar absorptance:0.2 \\
\hline & External walls \& roofs & Solar absorptance: 0.2 \\
\hline \multirow[t]{5}{*}{$\begin{array}{c}\text { Blow away - } \\
\text { (ventilation) }\end{array}$} & Day time & $\begin{array}{c}\text { Indoor temp of each zone }>23^{\circ} \mathrm{C} \& \text { external } \\
\text { temperature }<25^{\circ} \mathrm{C} \text {, may-sept }\end{array}$ \\
\hline & Day time & $\begin{array}{c}\text { Indoor temp of each zone }>23^{\circ} \mathrm{C} \& \text { external } \\
\text { temp }<\text { internal temp, may-sept }\end{array}$ \\
\hline & Night time & $\begin{array}{c}\text { Ventilation at a constant rate from } 23: 00- \\
7: 00, \text { for the period may-sept }\end{array}$ \\
\hline & Night time & $\begin{array}{c}\text { Ventilation when the indoor temp of each } \\
\text { zone }>23^{\circ} \mathrm{C}, 23: 00-7: 00 \text {, may }- \text { sept }\end{array}$ \\
\hline & Night time & $\begin{array}{l}\text { Ventilation when the outdoor temp }>15^{\circ} \mathrm{C} \text {, } \\
23: 00-7: 00 \text {, may-sept }\end{array}$ \\
\hline $\begin{array}{l}\text { Convection - } \\
\text { (ceiling fans) }\end{array}$ & Hybrid cooling & $\begin{array}{l}\text { Cooling setpoint at } 27.5^{\circ} \mathrm{C} \text { instead of } 26^{\circ} \mathrm{C} \text {, } \\
\text { increase of } 1{ }^{\circ} \mathrm{C} \text { assuming that the fans cover } \\
60 \% \text { of the thermal zone - TOTEE } 20701-1\end{array}$ \\
\hline
\end{tabular}


Table 10: Heating and cooling loads $\left(\mathrm{kWh} / \mathrm{m}^{2} / \mathrm{yr}\right)$ for the optimum building with all year operation

\begin{tabular}{|l|c|c|}
\hline \multicolumn{3}{|c|}{ Optimum buildings - ALL YEAR operated } \\
\hline & Heating Load $\left(\mathbf{k W h} / \mathbf{m}^{2} / \mathbf{y r}\right)$ & $\begin{array}{c}\text { Cooling Load } \\
\left(\mathbf{k W h} / \mathbf{m}^{\mathbf{2}} / \mathbf{y r}\right)\end{array}$ \\
\hline Present day & 21 & 8 \\
\hline $\mathbf{2 0 2 0}$ & 16 & 11 \\
\hline $\mathbf{2 0 5 0}$ & 13 & 15 \\
\hline $\mathbf{2 0 8 0}$ & 9 & 22 \\
\hline
\end{tabular}

Table 11: Heating and cooling loads $\left(\mathrm{kWh} / \mathrm{m}^{2} / \mathrm{yr}\right)$ for the optimum building with seasonal operation

\begin{tabular}{|c|c|c|}
\hline \multicolumn{3}{|c|}{ Optimum buildings - SEASONALLY operated } \\
\hline $\begin{array}{c}\text { Heating, cooling ventilation } \\
\text { Operation May - Sept }\end{array}$ & Heating Load $\left(\mathbf{k W h} / \mathbf{m}^{2} / \mathbf{y r}\right)$ & $\begin{array}{c}\text { Cooling Load } \\
\left.\mathbf{( k W h} / \mathbf{m}^{2} / \mathbf{y r}\right)\end{array}$ \\
\hline Present day & 1 & 6 \\
\hline $\mathbf{2 0 2 0}$ & 1 & 8 \\
\hline $\mathbf{2 0 5 0}$ & 1 & 13 \\
\hline $\mathbf{2 0 8 0}$ & 1 & 19 \\
\hline
\end{tabular}

Table 12: Heating and cooling loads for the 'all year operated' optimum buildings for the 3 climatic zones

\begin{tabular}{|l|c|c|c|c|c|c|}
\hline \multicolumn{7}{|c|}{ OPTIMUM BUILDINGS - ALL YEAR OPERATED } \\
\hline & \multicolumn{2}{|c|}{ HEATING LOAD $\mathbf{k W h} / \mathbf{m}^{2} / \mathbf{y r}$} & \multicolumn{3}{c|}{ COOLING LOAD $\mathbf{k W} / \mathbf{m}^{2} / \mathbf{y r}$} \\
\hline & $\begin{array}{c}\text { Patra } \\
\text { zone B }\end{array}$ & $\begin{array}{c}\text { Thessaloniki } \\
\text { zone C }\end{array}$ & $\begin{array}{c}\text { Iraklio } \\
\text { zone A }\end{array}$ & $\begin{array}{c}\text { Patra } \\
\text { zone B }\end{array}$ & $\begin{array}{c}\text { Thessaloniki } \\
\text { zone C }\end{array}$ & $\begin{array}{c}\text { Iraklio } \\
\text { zone A }\end{array}$ \\
\hline present day & 21 & 58 & 12 & 8 & 4 & 10 \\
\hline 2020 & 16 & 53 & 9 & 11 & 6 & 14 \\
\hline 2050 & 13 & 48 & 7 & 15 & 9 & 19 \\
\hline 2080 & 9 & 41 & 4 & 22 & 14 & 29 \\
\hline
\end{tabular}

Table 13: Heating and cooling loads for the 'seasonally operated' optimum buildings for the 3 climatic zones

\begin{tabular}{|l|c|c|c|c|c|c|}
\hline \multicolumn{7}{|c|}{ OPTIMUM BUILDINGS - SEASONALLY OPERATED } \\
\hline & \multicolumn{2}{|c|}{ HEATING LOAD $\mathbf{k W h} / \mathbf{m}^{2} / \mathbf{y r}$} & \multicolumn{2}{c|}{ COOLING LOAD $\mathbf{k W} / \mathbf{m}^{2} / \mathbf{y r}$} \\
\hline & $\begin{array}{c}\text { Patra } \\
\text { zone B }\end{array}$ & $\begin{array}{c}\text { Thessaloniki } \\
\text { zone C }\end{array}$ & $\begin{array}{c}\text { Iraklio } \\
\text { zone A }\end{array}$ & $\begin{array}{c}\text { Patra } \\
\text { zone B }\end{array}$ & $\begin{array}{c}\text { Thessaloniki } \\
\text { zone C }\end{array}$ & $\begin{array}{c}\text { Iraklio } \\
\text { zone A }\end{array}$ \\
\hline present day & 1 & 2 & 1 & 6 & 3 & 6 \\
\hline 2020 & 1 & 2 & 1 & 8 & 5 & 9 \\
\hline 2050 & 1 & 2 & 0 & 13 & 8 & 15 \\
\hline 2080 & 1 & 2 & 0 & 19 & 13 & 24 \\
\hline
\end{tabular}




\section{LIST OF FIGURES}

Figure 1: Map of Greece showing the climatic zones and the location of Patra (zone B), Thessaloniki (zone C) and Iraklio (zone A)

Figure 2: Ground floor

Figure 3: Northwest facade

Figure 4: Section showing the shading elements

Figure 5: Monitored data for temperature $\left({ }^{\circ} \mathrm{C}\right)$ for the area of Athens for the years 1970 $-2010$

Figure 6: Monitored data for relative humidity (\%) for the area of Athens for the years $1970-2010$

Figure 7: Hourly temperatures and diurnal differences for 3 days in August

Figure 8: Heating load for the period $1970-2010$

Figure 9: Cooling load for the period $1970-2010$ 


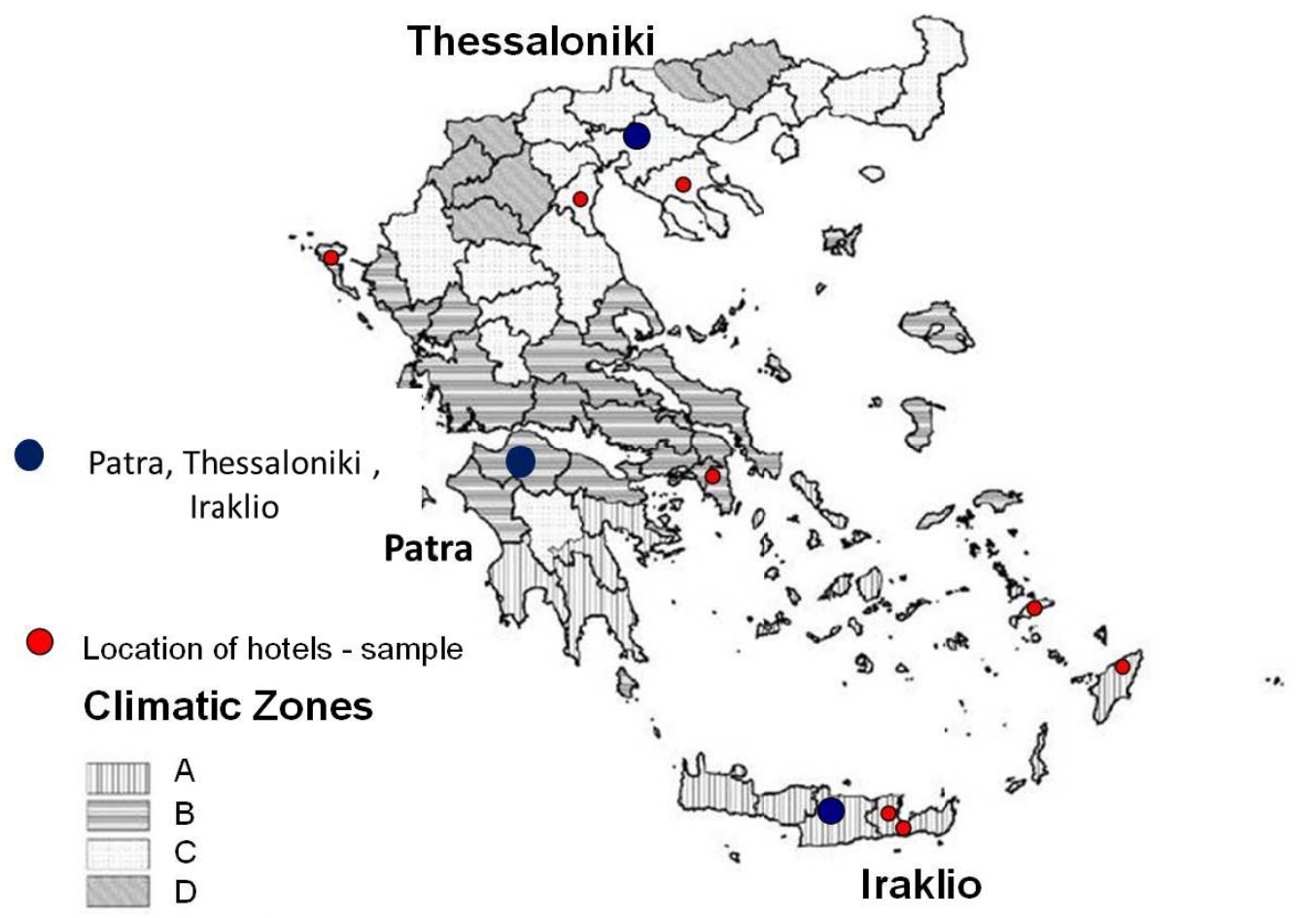

Figure 2: Map of Greece showing the climatic zones and the location of Patra (zone B), Thessaloniki (zone C) and Iraklio (zone A)

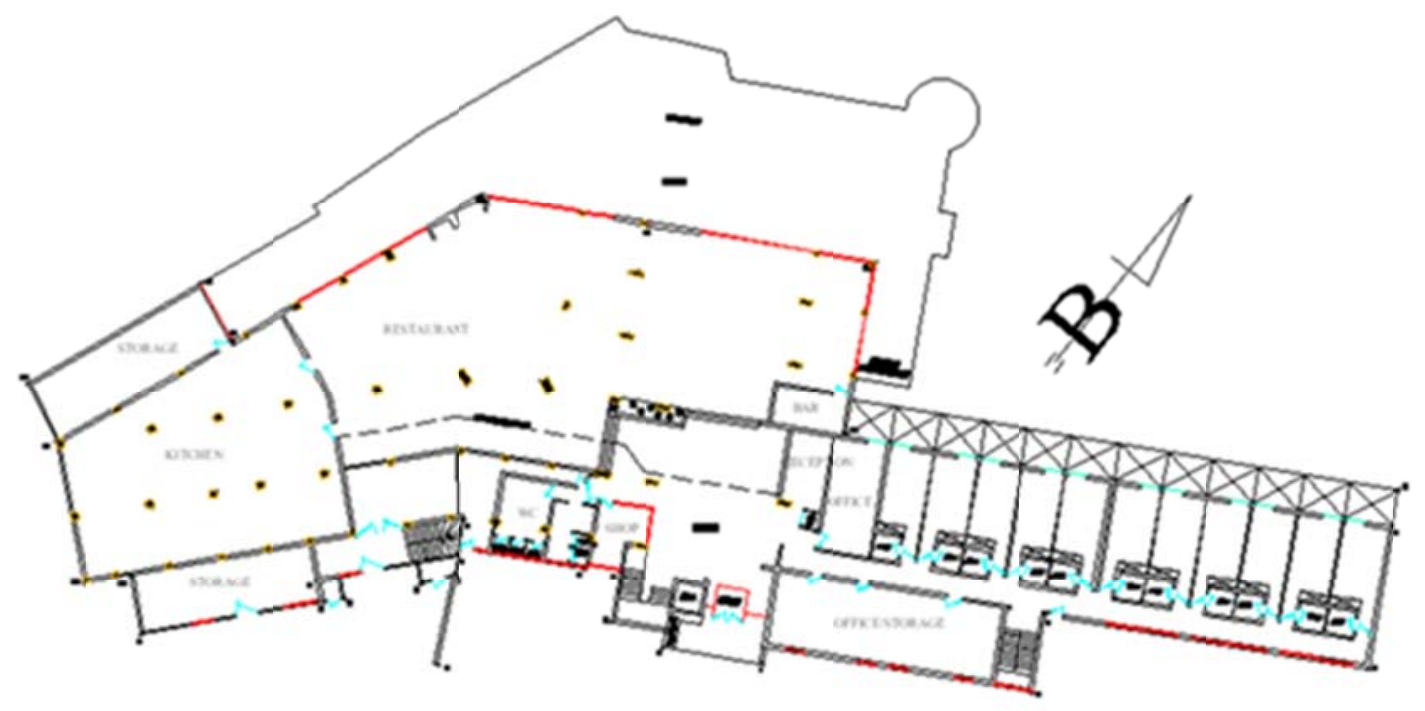

Figure 2: Ground floor 


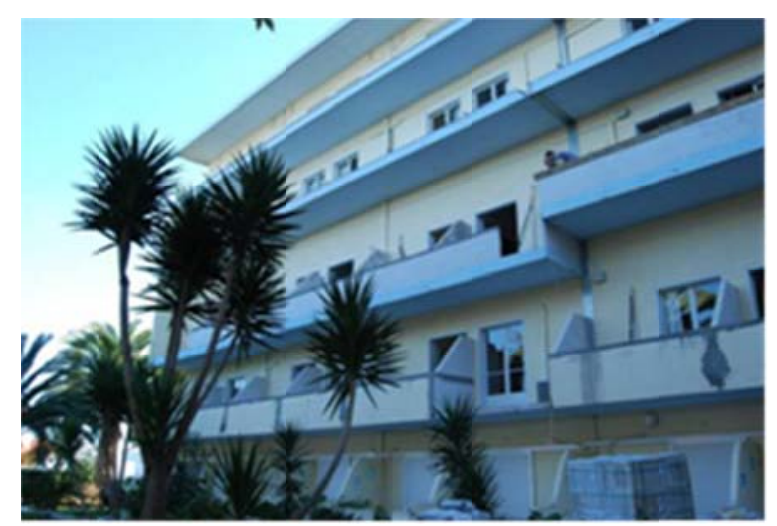

Figure 3: Northwest façade

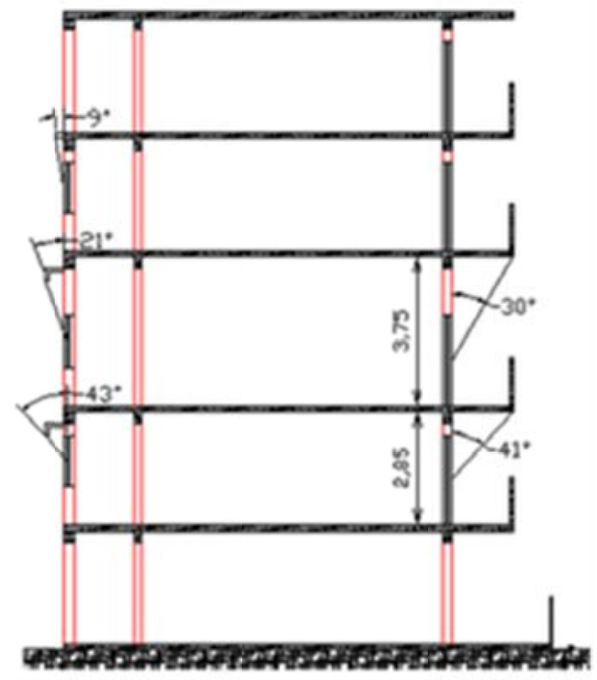

Figure 4: Section showing the shading elements 


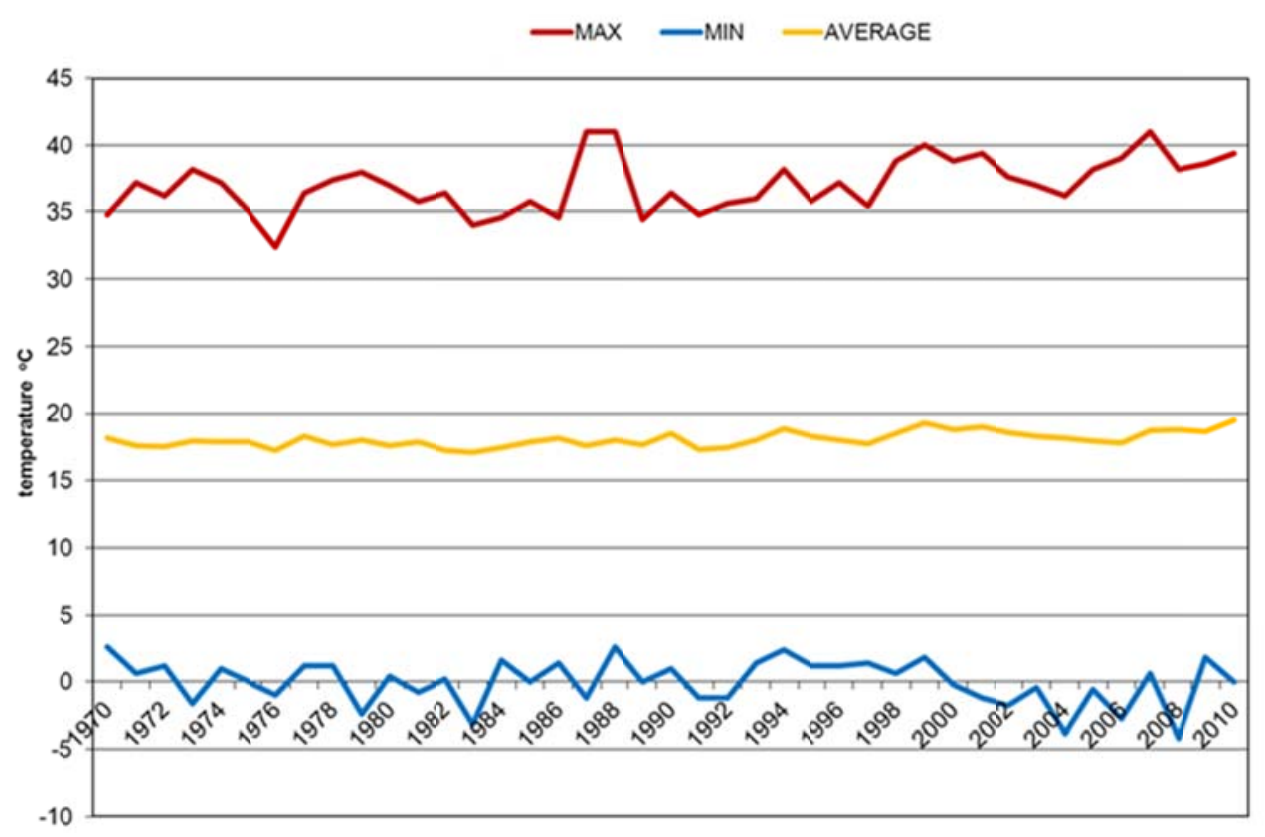

Figure 5: Monitored data for temperature $\left({ }^{\circ} \mathrm{C}\right)$ for the area of Athens for the years 1970 $-2010$

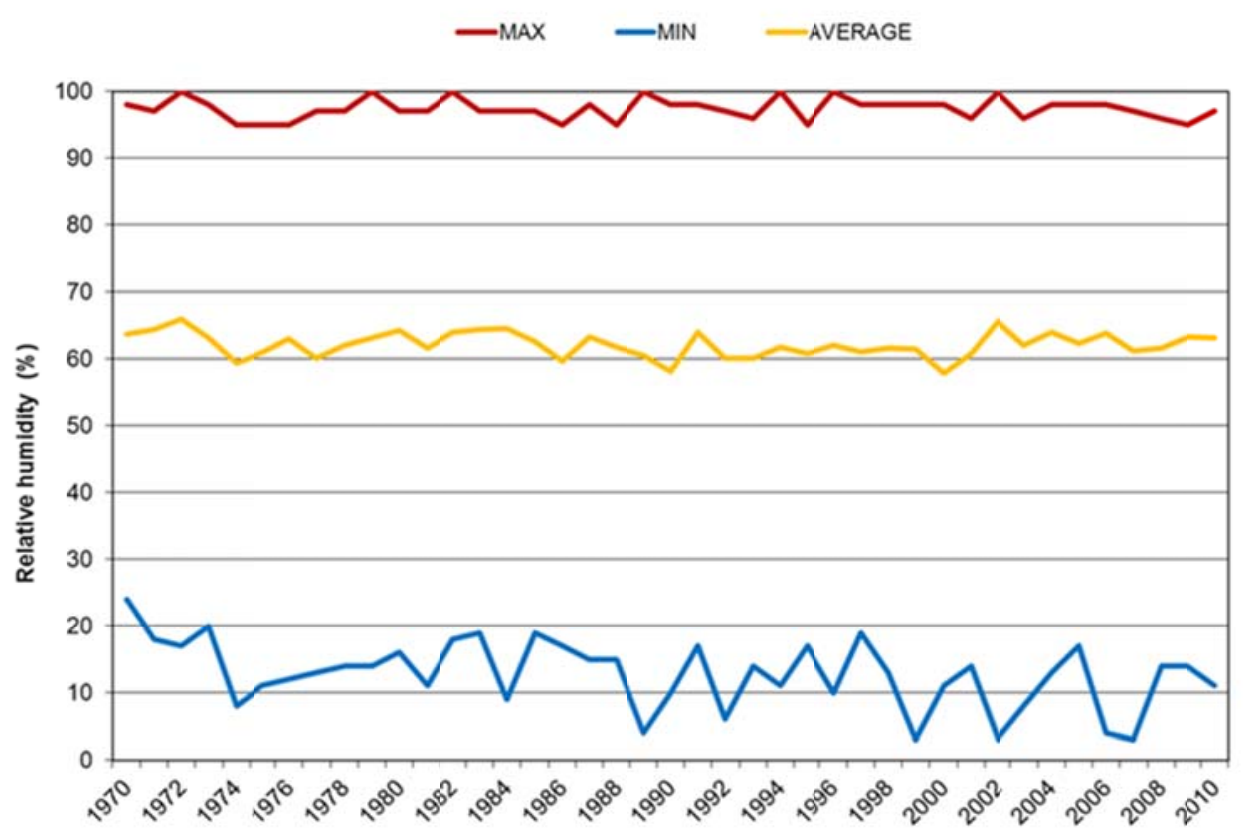

Figure 6: Monitored data for relative humidity (\%) for the area of Athens for the years $1970-2010$ 


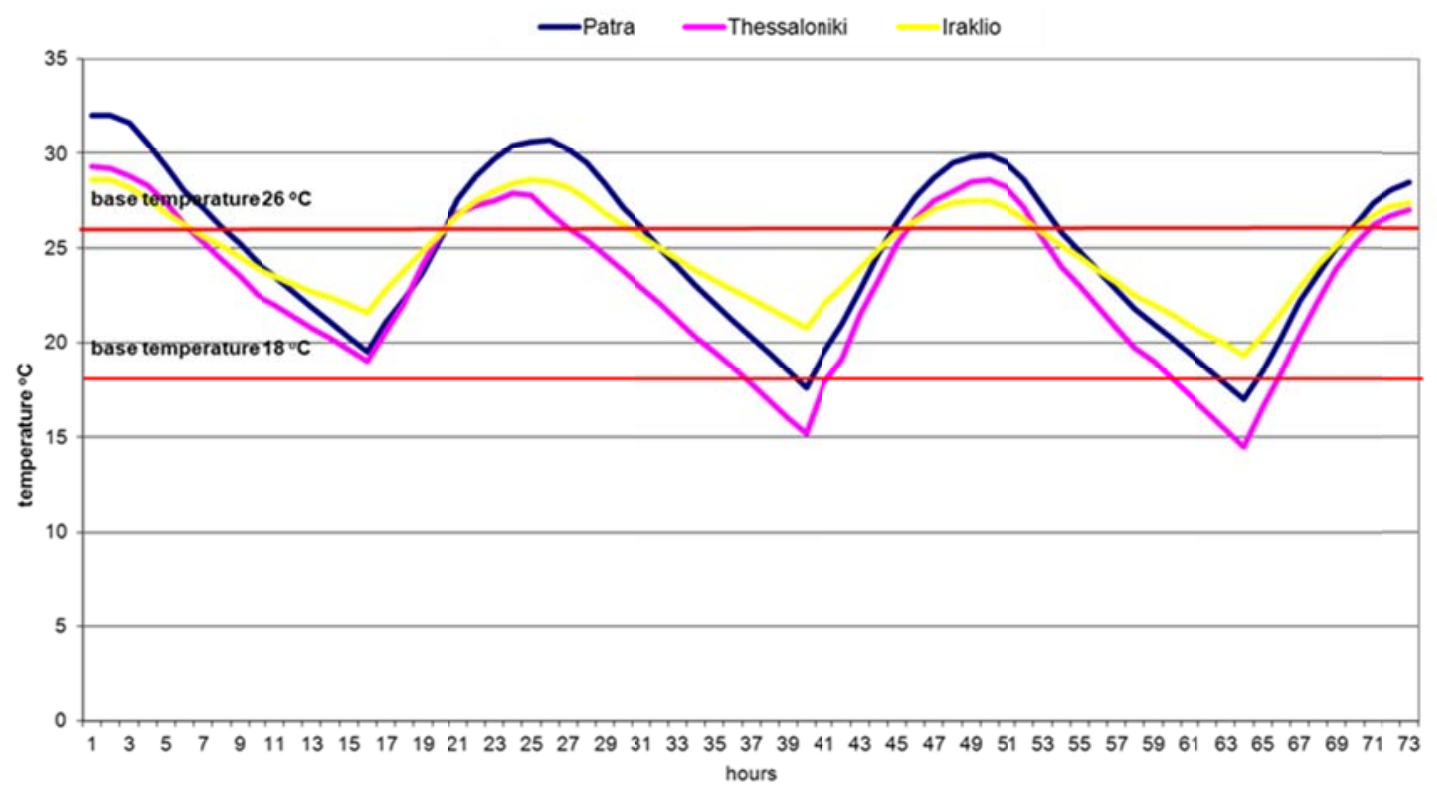

Figure 7: Hourly temperatures and diurnal differences for 3 days in August

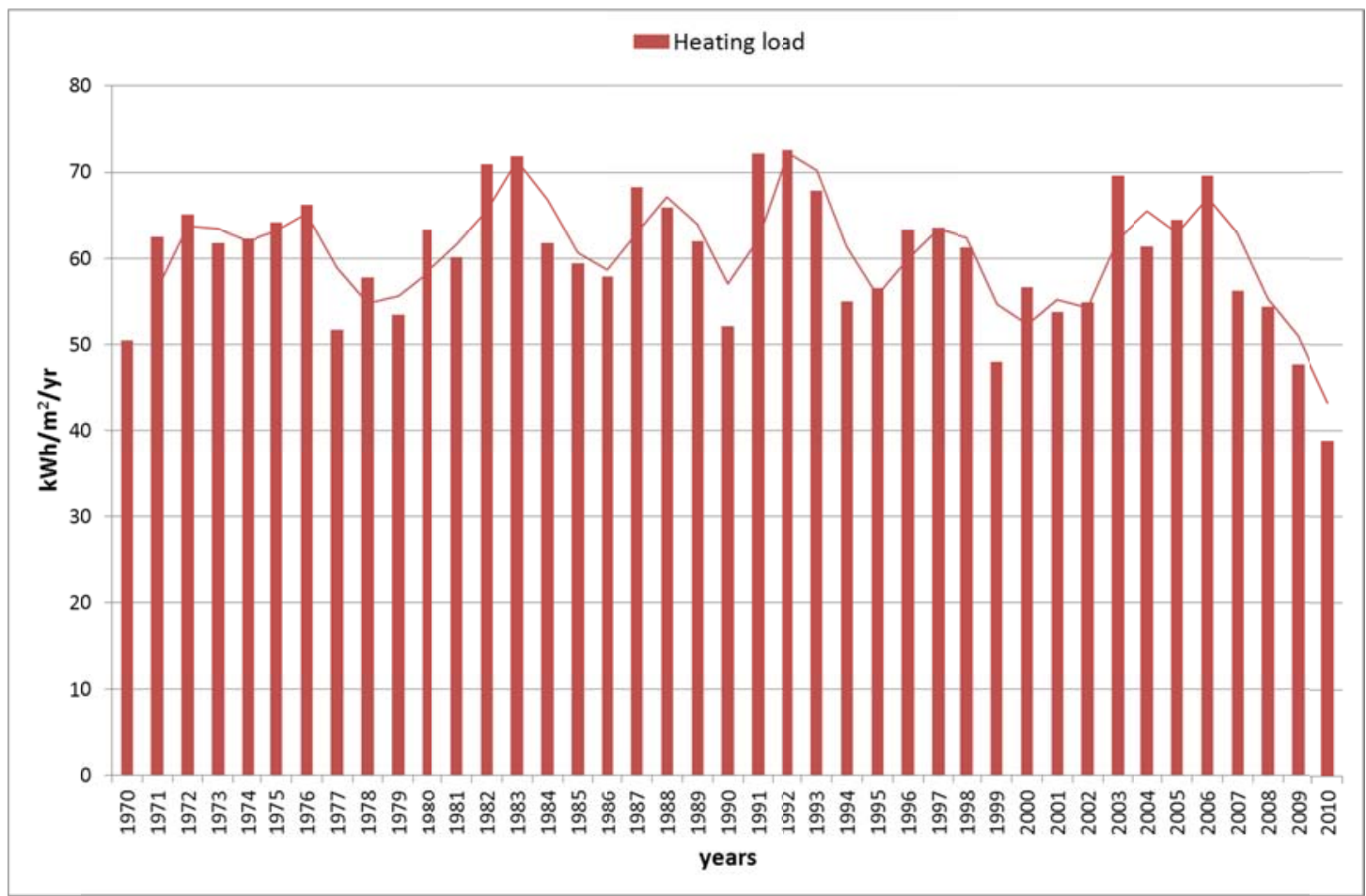

Figure 8: Heating load for the period $1970-2010$ 


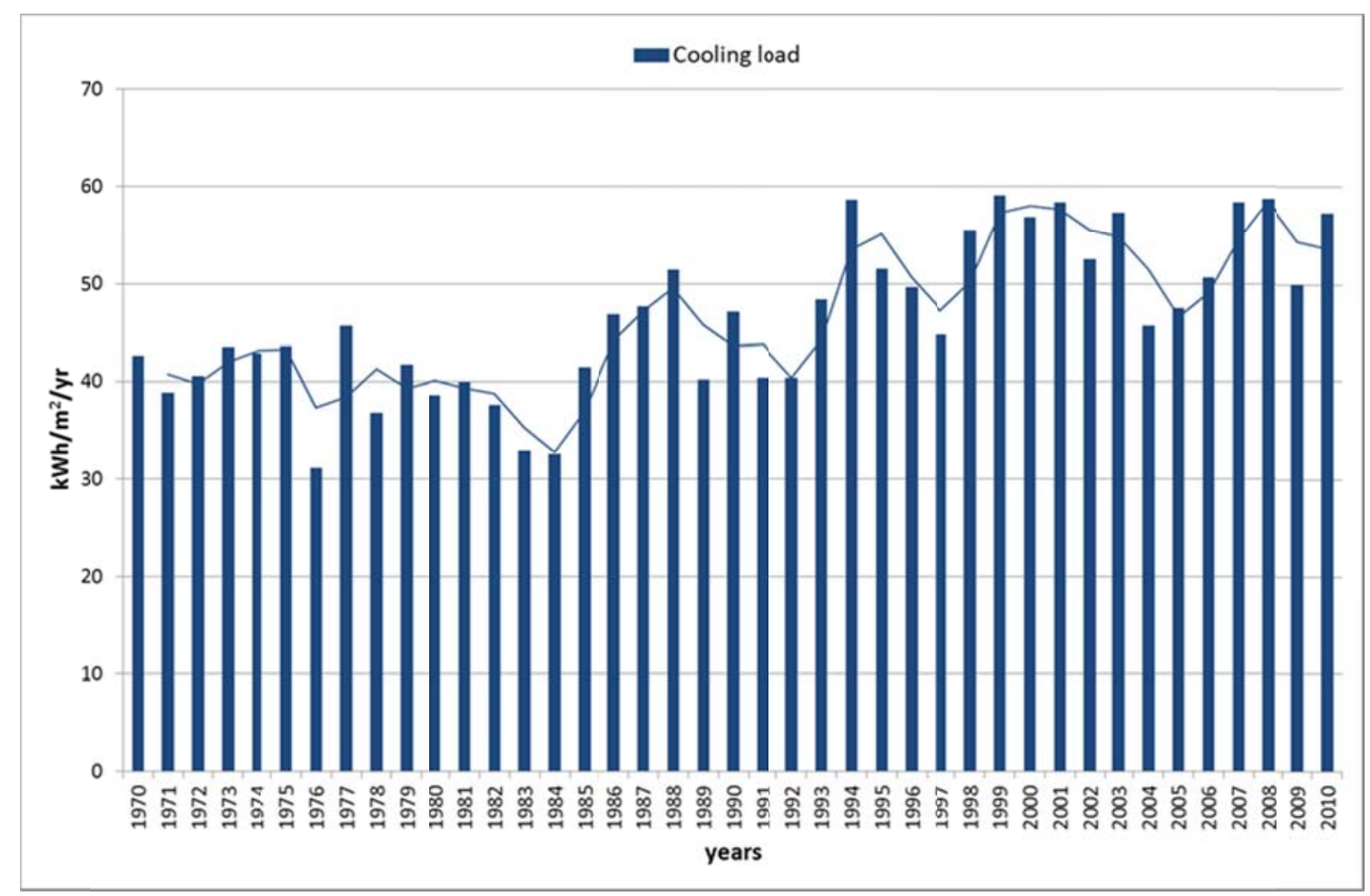

Figure 9: Cooling load for the period $1970-2010$ 